\title{
1h.2548
}

DOE/NASA CONTRACTOR REPORT

\section{DESIGN PACKAGE FOR PROGRAMMABLE CONTROLIER AND HYDRONIC SUBSYSTEM}

Prepared from documents furnished by

Sunkeeper Control Corporation

P. O. Box 34

Shawsheen Village Station

Andover, Massachusetts 01810

Und er Contract NAS8-32257 with

National Aeronautics and Space Administration

George C. Marshall Space Flight Center, Alabama 35812

For the U. S. Department of Energy

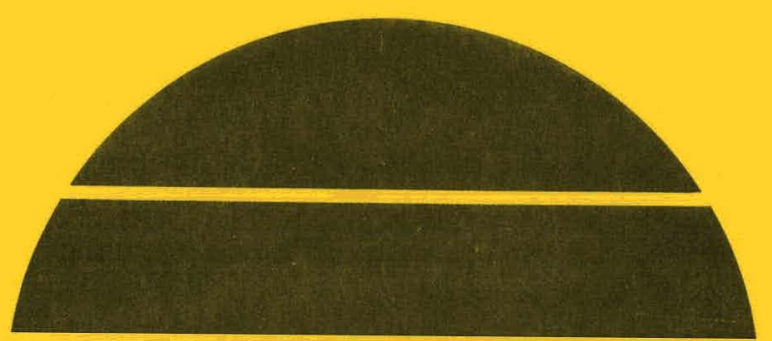

\section{U.S. Department of Energy}

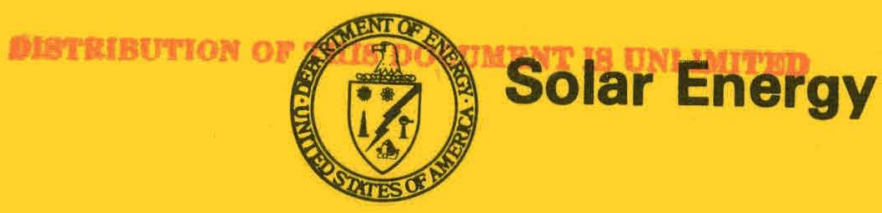




\section{DISCLAIMER}

This report was prepared as an account of work sponsored by an agency of the United States Government. Neither the United States Government nor any agency Thereof, nor any of their employees, makes any warranty, express or implied, or assumes any legal liability or responsibility for the accuracy, completeness, or usefulness of any information, apparatus, product, or process disclosed, or represents that its use would not infringe privately owned rights. Reference herein to any specific commercial product, process, or service by trade name, trademark, manufacturer, or otherwise does not necessarily constitute or imply its endorsement, recommendation, or favoring by the United States Government or any agency thereof. The views and opinions of authors expressed herein do not necessarily state or reflect those of the United States Government or any agency thereof. 


\section{DISCLAIMER}

Portions of this document may be illegible in electronic image products. Images are produced from the best available original document. 
This report was prepared to document work sponsored by the United States Government. Nelther the United States nor its agents the Unfted States Department of Energy, the United States National Afronautics and Space Adminletration, nor any federsl employees, nor any of tha contractors, sutcutractors or their employees, make any warranty, express or 1 ifflite, or assume any legal liabllity or responsibility for the sccuracy. completeness, or usefulness of any information, apparatus, product or process disclosed, or represent that its use would not infinge privately owned rights. 


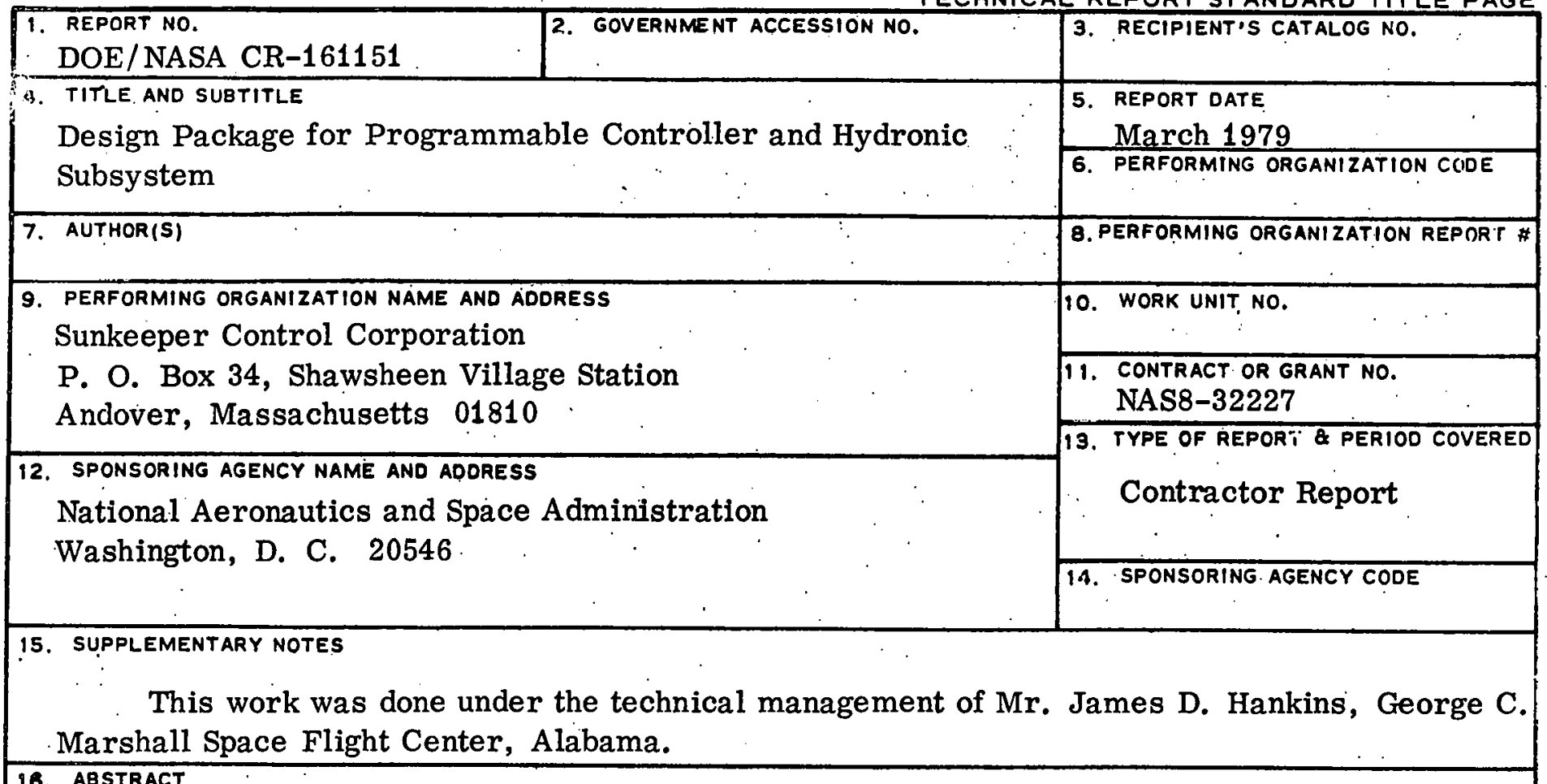

This report contains information used in the evaluation of design of Sunkeeper Control's electronic controllers and hydronic packages. Some of the information includes system performance specification, design data brochure, drawings, and qualification and acceptance test procedures.

Some retyping and formatting have been done for clarity.

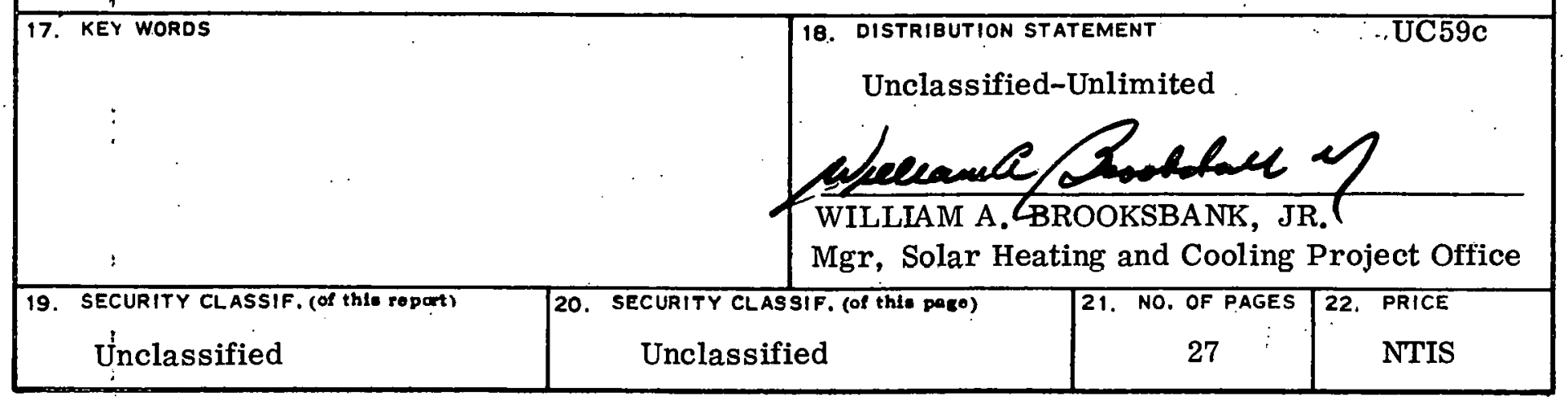


THIS PAGE

\section{WAS INTENTIONALLY LEFT BLANK}


TABLE OF CONTENTS

Performance Specification 1

Design Data Brochure 4

Installation Drawing $\quad 12$

Assembly Drawing . 13

Qualification \& Acceptance Test Procedures 14

This repon was prepased as an eccount of work

sponsored by the United States Govermment. Neither the

United States nor the United States Department of

Energy, nor any of their employees, nor any of their

contractors, subcontractors, or their employees, makes

any warranty, express or implied, or assumes any lega

liability or responsibility for the accuracy, completeness

or usefulness of any information, apparatus, product or

process disclosed, or represents that its use would not

infringe privately owned rights.

iii

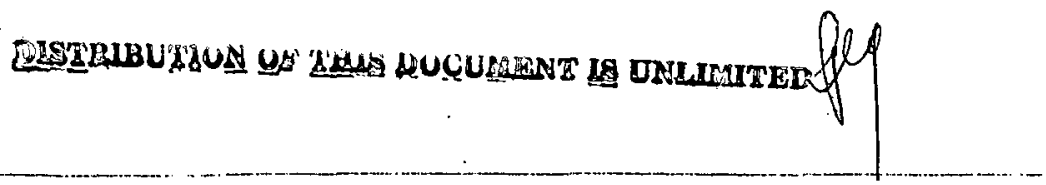


ANDOVER CONTROLS CORPORATION

I. P. E. C. H. SUBASSEMBLY MODEL 1070

PERFORMANCE SPECIFICATION

\section{SUBSYSTEM ENVIRONMENT}

Temperature: $40^{\circ}$ to $100^{\circ} \mathrm{F}$

Relative Humidity: $5 \%$ to $95 \%$

Primary Power: $117 \pm 10 \%$ Volts, single phase, three wire 60HZ., 30 amp service.

\section{SOLAR COLLECTOR CIRCULATION SYSTEM}

Flow Rate: $1.8 \mathrm{gal} / \mathrm{minute} / \mathrm{zone} \pm 10 \%$

Max. Pressure: 30 PSI

Pressure Head: 20 feet maximum

Fluid Temperature: $240^{\circ} \mathrm{F}$ Max.

Pump Control: Manual or Automatic

Pump Duty Cycle: Up to $100 \%$, under program control

Automatic Valves: Eight electrically valved ports for array control at 3. $3 \mathrm{Cv} /$ valve.

ZONE WATER SYSTEM

Flow Rate: 5 gal $/$ minute/zone $\pm 10 \%$

Max. Pressure: 30 PSI

Pressure Head: $30 \mathrm{ft}$. Max.

Fluid Temperature: $240^{\circ} \mathrm{F}$ Max.

Pump Control: Manual or Automatic

Pump Duty Cycle: Up to $100 \%$, under program control

Automatic Valves: Eight electrically valved ports for zone control at 4. $1 \mathrm{Cv} /$ valve.

COLLECTOR PANEL MANIFOLD VALVE MODULE

Max. Pressure: 125 PSI

Valve Actuator: 6 Watts at $24 \mathrm{~V}$

Valve Actuation Time: 15 Seconds Maximum

Max. Temperature: $240^{\circ} \mathrm{F}$

Pipe Size: $3 / 4$ Inch Output, $11 / 2$ inch inlet

ZONE MANIFOLD VALVE MODULE

Max. Pressure: 125 PSI

Valve Actuator: 6 Watts at $24 \mathrm{~V}$

Valve Actuation Time: 15 Seconds Maximum

Max. Temperature: $240^{\circ} \mathrm{F}$

Pipe Size: 1 inch Output, $11 / 2$ inch inlet 
$\underline{\text { PHYSICAL }}$

Size: $32^{\prime \prime} \mathrm{D} \times 6^{\prime} \mathrm{H} \times 4^{\prime} \mathrm{W}$

Weight: Approximately 400 pounds

DESIGN LIFE

Hydronics: 20 years

Controller: 20 years

ANALOG INPUTS

Thermistor: Quantity of 24, compatible with Fenwal type UUT43J1 bead

Voltage: Quantity of 8,0 to 5.110 volts., $\mathrm{Z}$ in $>3 \mathrm{~K} \Omega$

SWITCH INPUTS

Quantity: 32

Rising Threshold: 9.2 - 15.5 volts

Falling Threshold: $1.75-7.3$ volts

Input Impedance: $1.5 \mathrm{~K} \Omega$

State Definition: Open $=$ Gnd $=$ OFF

LED Indicators: Light when input is $O N$

DIGITAL OUTPUTS

Quantity: 32 (16 used to control I. P.E. C. H. Zones)

(16 Available to User)

Current Capability: . 100mA sink Max.

Voltage: Clamped to $+24 \mathrm{v},-0.3 \mathrm{v}$

LED Indicators: Lights when associated output is closed to ground. (Sinks current)

VOLTAGES (Available to User)

$+5,+24, \pm 12$ volts at $250 \mathrm{~mA}$. each Max.

OVERVOLTAGE PROTECTION

Inputs and Outputs withstand monetary short to 120 VAC.

MODERN CHANNEL

Interface: RS232-C

Band Rate: Selectable 110, 300, 9600, or 19200. 


\section{REAL TIME CLOCK}

Calender: Automatic Calender good to year 2000

Battery-Backup: Real time clock switches from $60 \mathrm{HZ}$ line control to quartz crystal: Back-up good for two days minimum. Batteries recharge after power up.

\section{PROGRAMMABILITY}

The Sunkeeper control language simplifies the use of the controllers capabilities. With a single statement, it specifies the analog and digital input conditions under which the unit turns digital outputs $O N$ and $O F F$. The unit can also vary the action of the control programming depending on the time of day or time of year. It is also supported by 160 interval timers: 40 seconds timers, 40 minutes timers; 40 hours timers and 40 days timers. Timers have a capacity of up to 256 units.

Analog input voltages are automatically converted to appropriate units so that limit points are in terms of degrees per volts. The automatic scaling simplifies the control programming and makes it easy to understand and maintain. 
DESIGN DATA BROCHURE

A) : GENERAL DESCRIPTION $-\frac{\text { INTEGRATED PROGRAMMABLE ELECTRONIC CONTROLLER. }}{\varepsilon \text { HYDRONIC SUB-SYSTEM }}$

The Sunkeeper I.P.E.C.H. subsystem is a completely assembled, piped, wired and tested package. It is designed to be used in large residential and small commercial solar heating applications. The package consists of three basic systems, a power panel and programmable microprocessor, a hydronic solar collection pumping system and a hydronic heating hot water pumping system.

The package requires only field connection of piping, power and sensor devices. It may be programmed to collect solar energy from the user's collector based on a number of user determined inputs such as solar insolation, date, time of day, outdoor ambient conditions, etc.: In addition, it may be programmed to heat various zones of the user's facility as determined by user installed zone thermostats or to store collected solar energy in user supplied storage tanks. Once user supplied inputs are connected, sequence of operation, set-points, and priorities may be changed at will without the need for field wiring changes.

The user may, through the use of a compatible portable printer terminal, have access to the controller either on site or remotely by telephone. mode:.. Access features include a 32 hour history file of user selected data, print-out of all inputs and outputs, location of coritrol sequence in program, ability to edit program and program print-out. In addition, the controller may be connected to a remote master computer fur dala logging or master command, interrogation or program editing. 
DESIGN DATA BROCHURE

PARTS \& MATERIALS

SPECIFICATIONS

(B)

1. General Description

2. Piping

3. Fittings

4. Control Valves

5. Constant Flow Control Devices

6. Valves

7. Strainers

8. Pressure Gauges

9. Pumps

10. Hangers

11. Structural Frame

12. Insulation 
1. General Descriṕtion

a) The mechanical sub-system shall be a completely assembled and tested package. The package shall consist of all required piping, fittings, valves, control valves, constant flow. control devices, strainers, pressure gauges, pumps, hangers, piping insulation, integrated programmable controller, motor starters, convenience outlets, relays, transformers, wiring, all mounted on a structural steel frame suitable for.

$\therefore$ shipplng. The package shall require only field conncctions to piping, power wiring and sensor device wiring.

b). The dimensional requirements given on the drawings are based on the names of manufacturers materials given in the following specifications. Substitutions shall require a review of the drawings for dimensional compatibility.

\section{Piping}

a) All piping shall be type $L$ copper tubing as manufactured by Aitucoilda American Brass Company. All tubing shall be manufactured in accordance with Federal Specification WW-T-799A and ASTM B-88.

b) All soldered joints shall be made with 95-5 tin-antimony or 95-5 tinlead per ASTM B-32, Grade 5A. All ends of tubing shall be reamed after cutting to remove burrs and tubing and fittings cleaned bright with emery cloth before application of flux and soldering joints.

3: Fittings

a) All fittings shall be wrought copper or cast brass as shown on the drawings. All fittings shall be Anaconda American Brass Co. or equal. "Wrought copper 
fittings stiall meet A.S.A. Std. B $6.22-1951$ and all cast brass fittings shall meet A.S.A. Std. B-16.18-1950. Threaded ends shall conform to American Standard Taper Pipe Thread (N.P.T.), A.S.A. B2.1.

4. Control Valves

a) All control valves shall be Bell \& Gossett Modumate Zone Control Valves of the two-way pattern type. Valves shall be for 24 Volt operation and

$\therefore \because$ of the normally closed type. A removable heat motor shall drive the valve to the open position. The valve body shall be of cast brass, the seal cartridge shall be of stainless steel and brass construction. All operating components shall be enclosed in a steel cover and frame. Valve shall provide $100 \%$ close off at pump heads to $60 \mathrm{ft}$. Valve shall have a manual operating lever and valve position shall be externally indicated. Valve shall be suitable for 125 p.s.i.g. operating pressure at $40^{\circ}$ to $240^{\circ} \mathrm{F}$.

\section{Constant Flow Control Devices}

a) Constant flow control devices shall be as manufactured by Griswold Controls, Santa Ana, California. Valves shall be factory calibrated, direct acting, automatic pressure compensating type, and shall limit flow rates to within $\pm 5 \%$ accuracy. Control mechanism shall be of stainless steel construction. Body" shall be of wrought-copper construction suitable for sweat-type installation.

6. Valves

a) Gate valves, ball valves and check valves shall be as manufactured by Jenkins Brothers. Gate valves shall be solder end type and bronze con- 
constructión for $200 \mathrm{lb}$. non-shock cold water service, Jenkins Fig. 1240. Ball valves shall be forged bronze solder end for 400 lbs. non-shock cold water, oil or gas, Jenkins Fig. 1100-T with tefion seal. Check valves shall be bronze swing type solder end for 300 lbs. non-shock cold water, Jenkins Fig. 1222.

b) Balancing valves shall be Bell \& Gossett circuit setter balance valve; bronze construction with bronze disc, for 125 p.s.i.g. service at maximum $250^{\circ} \mathrm{F}$. Valve shall have solder ends, integral pointer and scale to indicate position, and provision for connection to portable differential pressure meter. Connections for meter shall have built-in check valves.

\section{Strainers}

a) Strainers shall be liueșsco, Muller Steam Specialty Co., Brooklyn, N.Y. No. $352-1 / 2$ with solder ends, perforated Monel screens with 1/16" perforation for water service, for 250 P.S.I. SWP at $425^{\circ} \mathrm{F}$ service.

\section{Pressure Gauges}

Pressure gauges shall be Marsh Instrument Company copper alloy bourdon tube type $14148,21 / 2^{\prime \prime}$ dial size, 0 - 100 P.S.I. range with 1/8". N.P.T. bottom male threaded connection.

\section{Pumps}

a). Pumps shall be Bell \& Gossett Series 60 in-line circulators, Models 60-15, 60-16 or $60-17$ as required.' Pump shall be single stage vertical split case design all bronze construction, with enclosed type impellor, hydraulically and dynamically balanced. Pump shall have mechanical seal of. carbon (Remite), oil lubricated journal bearings, hardened alloy steel shaft, shaft sleeve, flexlble coupling between motor and shaft, and 
resilient mounted motor for $115 / 230 \mathrm{~V}$. 3. phase $60 \mathrm{~Hz}$. service.

10. Hangers

a) All pipe hangers shall be I.T.T. Grinnell. The following models shall be provided.

Figure $138 R$ extension split pipe clamp for $3 / 8^{\prime \prime}$ threaded rod...

Figure $128 \mathrm{R}$ rod threaded flange for $3 / 8^{\prime \prime}$ threaded rod. Fiange stiall have two countersunk holes to accept 12-32 screw for mounting.

Figure 120 light weight $U$-bolt, $1 / 4^{\prime \prime}$ diameter threaded $1 / 4-20$ and two $1 / 4-20$ hex-nuts each.

11. Structural steel Frame

a) A structural steel frame shall be shop fabricated as shown on the drawirigs. This frame shall support all components of the mechanical sub-system and used in conjunction with wood blocking shall be used for shipping purposes.

b) The frame shall be entirely constructed of A.S.T.M. A-36 structural steel. All joints shall be electric resistance arc welded, frame shall be cleaned, prime coated with red-lead and painted."

12. Insulation

All piping and fittings shall be insulated and covered with $1 / 2^{\prime \prime}$ thick Armaflex fire rated insulation. 
C) SUBSYSTEM PERFORMANCE SPECIFICATIONS

SUBSYSTEM ENVIRONMENT

TEMPERATURE:

RELATIVE. KUMIDITY:

PRIMARY POWER:

$40^{\circ}$ to $100^{\circ} \mathrm{F}$

$5-95 \%$ non-condensing

$117+10 \%$, single phase, two wire

HYDRONICS

COLLECTOR CIRCULATION SYSTEM
FI ONW RATE:
MAX PRESSURE:
$15 \mathrm{gai} . / \mathrm{min}$.
PRESSURE HEAD:
30 PSI
20 feet maximum
FLUID TEMPERATURE: $\cdot 240^{\circ} \mathrm{F}$
PUIP DUTY CYCLE: $\quad 100 \%$
UP TO EIGHT (B) ELECTRICALLY VALVED PORTS FOR ARRAY CONTROL AT $3.3 \mathrm{CV} /$ VALVE

\section{ZOHE WATER SYSTEH}

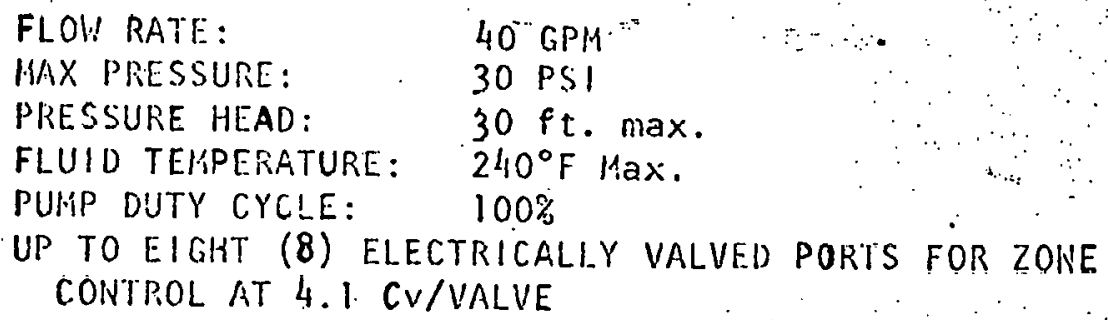

COLLECTOR PAIVE. MANIFOLD VALVE MODULE

MAX. PRESSURE:

VALVE: ACTUATOR:

VALVE ACTUATION

MAX TEMPERATURE:

PIPE SIZE:
125 PSI

6 Watts 24 VAC

10 Seconds $240^{\circ} \mathrm{F}$

$3 / 4$ Inch cutput, 1 1/2 Inch Inlet

ZONE MANIFOLD VALVE MODUIE

MAX. PRESSURE.

VALVE ACTUATOR:

VALVE ACTUATIOH TIME:

MAX. TEMPERATURE:

PIPE SIZE:
125 PSI

6 Watts @ 24VAC

10 Seconds

$240^{\circ} \mathrm{F}$

1 Inch Output, I 1/2 Inch Inlet 
: CONTROL IS AVAILABLE FOR UP TO I HP PUMP.

PHYSICAL SIZE

SIZE: Dust Tight: NEMA Cabinet $32^{\prime \prime} \times 4^{\prime} \times 6^{\prime}$ Height SUBSYSTEM WEIGHT: Approximately 900 pounds

DESIGN LIFE

DESIGN LIFE OF ALL SUBSYSTEM MODULES: 20 Y'earS

CONTROLLER

POWER: IITVAC $+20 \%, 60 \mathrm{~Hz}, 25$ Watts

SIZE: $24.0^{11} \times 16.0^{11} \times 4.75^{11}$

ANALOG INPUTS

THERHISTOR: Potentiometric measurement with pull

ANALOG: up resistor $(3 K \Omega)$ to $+6.2 V$

.0 to $6.2 \mathrm{~V} ., \mathrm{Zin} \geqslant 3 \mathrm{~K}$

SWITCH INPUTS

RISING THRESHOLD: $9.2-15.5$ Volts

FALLING THRESHOLD: $1.75-7.3$ Volts INPUT IMPEDANCE: $1.5 \mathrm{~K}$

STATE DEFINITION: OPEN $=$ GND $=$ OFF

LED INDICATOR WITH EACH INPUT

DIGITAL OUTPIT

CURRENT CAPABILITY: $100 \mathrm{~mA}$ sink max.

VOLTAGE: Clamped to +24V, $-0.3 \mathrm{~V}$

LED INDICATOR WITH EACH OUTPUT

VOLTAGES (AVAILABLE FOR USER)

$+5,+8,+24,+12$ Volts Available On Connectors

(3) $250 \mathrm{~mA} \mathrm{Max.} \mathrm{Each}$ 


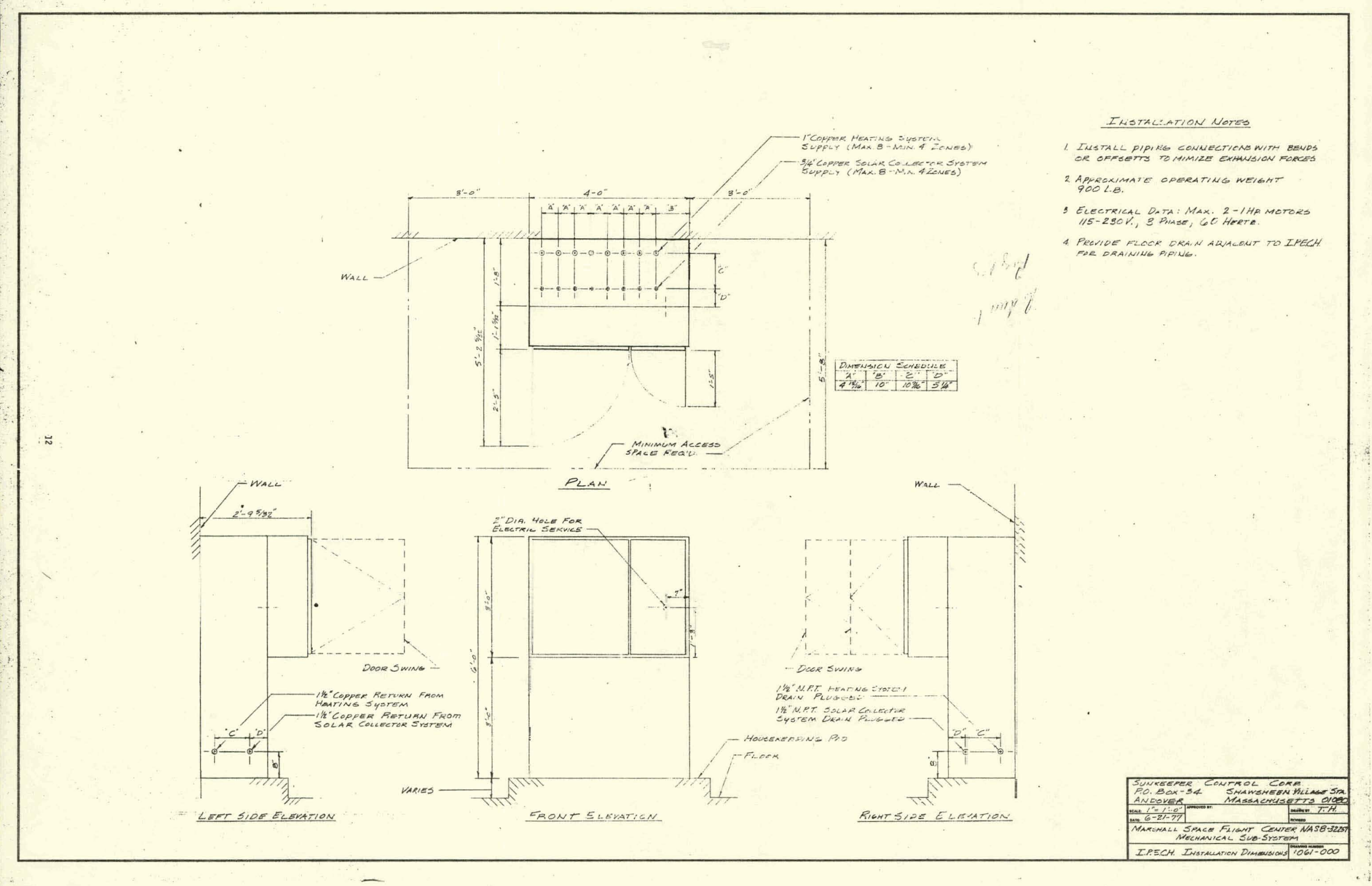




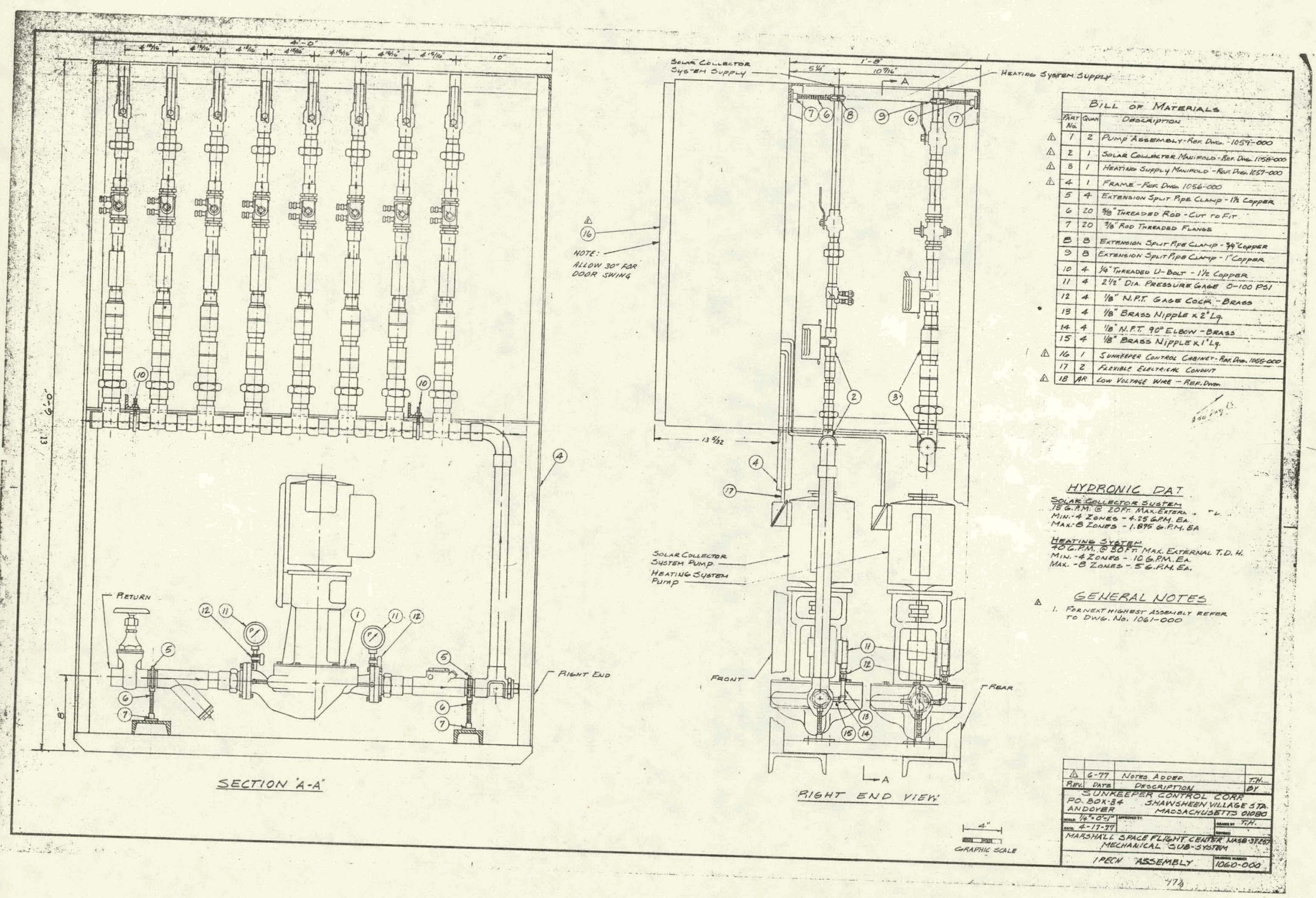


DATA REQUIREMENT NO. 505-13

Contract No. NAS8-32257

QUALIFICATION \& ACCEPTANCE TEST PROCEDURES

1. ITEMS TO BE TESTED

(The following data shall be recorded)

A) Sunkeeper Controller

Model No.

Volts

Serial No.

Phase

A.C.

Power

Watts

Cycle

$\mathrm{Hz}$

B) Solar Collector System Pump

Mfg.

Model No.

Serial No.

HP

Volts

$\mathrm{PH}$

Cycle

$\mathrm{Hz}$

Amps

c) Heating System Pump

Mfg.

Model No.

Serial No.

HP $\quad$ Volts $\quad \mathrm{PH} \quad \mathrm{Hz}$

Amps

D) Zone Control Valves

Mfg.

Model No.

Volts

Amps

Size

Cycle $\mathrm{Hz}$

$\mathrm{PH}$

E) Balancing Valve

Mfg. Model No. Size

F) Constant Flow Controls

Mfg. Model No.

Flow Rate G.P.M., Control Range

Size

G) I.P.E.C.H. Sub-Assembly

Mfg.

Model No.

Serial No. 


\section{TEST OBJECTIVES}

The object of these tests shall be to simulate operating conditions specified for the I.P.E.C.H. Sub-Assembly. These performance specifications shall be as listed in "Subsystem Performance Specifications" of Prototype Design Review Data Article No. 505-8. In addition, data accumulated during these tests shall be used to support responses to Performance Requirements listed in the Verification Cross Reference Matrix.

I11. LOCATION \& SC.HEDULE OF TESTING

All testing shall be performed at Sunkeeper Control Corporation's manufacturing facilities in Andover, Massachusetts. Testing of the first article is planned to commence during the last week of August 1977.

\section{TEST PREREQUISITES FOR PASSING OR FAILING}

All incoming materials shall be inspected for damage and compliance with Sunkeeper Control Corporation's procurement specifications. Damaged materials or those not in compliance shall be rejected and replaced.

During assembly of the Sunkeeper Controller, all P.C. boards and sub-assemblies are inspected for compliance with drawings and specifications. Diagnostic tests are performed during assembly to verify proper function of all circuitry. All circuitry that fails diagnostic tests are replaced prior to final assembly.

After all components have been inspected and tested, the I.P.E.C.H. package shall be assembled and wired. Operational test shall then be performed. The I.P.E.C.H. package shall operate within specified limits. Failure to do so shall result in rejection of the package. Repair, replacement of components or redesign as required until package operates within specified limits. Operation within specified limits shall result in acceptance.

\section{v. TEST PROCEDURE}

\section{A) Sunkeeper Controller}

The Sunkeeper Controller is subjected to five tests for acceptance. Three of the tests are analytical circuitry checks. One test verifies interface checks. One test exposes the controller to the specified environment to determine that the controller will function properly. 
The Power-On Test checks that the proper voltages are available at. various locations in the circuitry. The lower Random Access Memory (RAM) test is used to verify proper function of memory bits and addressing function. The upper Random Access Memory (RAM) test verifies proper function of upper RAM by using a preprogrammed PROM to exercise this memory. In addition it verifies that memory is retained during power "off" periods.

The hardware interface test is used to check all inputs and output functions by using a test box to simulate actual operating conditions. The environmental test verifies controller operation in the specified environment. A simple program is entered into the controller. The controller is installed in a test chamber. Power is turncd "on" and "off" randomly while program function is observed. Controller must process the proyram during environmental extremes and not lose the program during power "off" periods, thus verifying proper function of battery back-up.

1) Power "On" Test: Techtronics 465 Oscilliscope

A. With $F B-1-4 \& R-89,116,117$ not installed

B. Location FB-1 Measure $+12 V D C$

C. Location FB-2 Measure +5VDC

Inductor

D. Location FB-3 Measure -5VDC

E. Location FB-4 Measure -12VDC

F. Location $R-89$ Measure +8VDC

G. Location $R-116$ Measure +24VDC

Resistor

H. Location R-117 Measure +4VDC.

1. Install FBI-4, \& R-89, $116,117$.

J. Location U-118 Pin 7 Measure +2 VDC

(Trim with R-192)

Integrated Circuit

K. Check all again

L. Check voltage indicator LED's "ON" at

following locations: $+24,+12,+5$,

$-5,-12$, 5V O.K., AC 0.K.

M. If all good readings, power test acceptable.

11) Lower Random Access Memory Test

A. Power "OFF"

B. Insert Programmable Read Only Memory (PROM) in F.C. address socket

C. Connect Lear sieyler Inc. ADM-3A vidèo terminal

D. Apply Power "ON"

E. Audible signal bell "ON" - "OFF"

F. Terminal display

Zero bits test complete

Ones bits test complete

odd bits test complete

Even bits test complete

Addressing test complete

Continue above test loop if passed until power "OFF"

G. If any of the first four tests failed terminal displays:

ERROR!!! trigger analyzer at FC-5I. 

H. If addressing test failed terminal displays: ERROR!!!
Trigger analyzer at FC80.
i. If any test failed, troubleshoot with Hewlett-Packard $1611 \mathrm{~A}$ logic state analyzer. Remove or replace or repair components as required. Repeat test until all complete.

\section{1) Upper Random Access Memory Test}
A. Power "OFF"
B. Remove PROM from F.C. address socket
C. Install PROM identified "H" bug in F.C. address socket
D. Install memory test PROMs EO in address socket, FO in address socket.
E. Power "ON"
F. Audible signal "ON" - "OFF"
Terminal displays asterisk
G. Open appropriate memory addresses, input upper and lower memory test limits, close addresses.
H. Initiate RAM test through terminal unit. Terminal unit displays less than () symbol when ready.
1. Run following test by inputing at terminal unit:
"AT" - Addressing test
"pp" - Ping pong test (odd/even bit)
"RT" - Random pattern test
"RP" - Repeat Pong Test
Power "OFF"
Allow 30 seconds minimum power "ON"
Reinitiate memory test "VP" - Verify pong test
J. If test passed, terminal displays "ADDRESS IS", "SHOULD BE" and "E.O.T." End of Test.
K. If test failed, terminal will display that address that failed, what the data "is" at that address, and what it "'should be".
L. Troubleshoot RAM with H.P. I6IIA analyzer. Remove or replace or repair faulty components.
M. Terminate memory test.

IV). Hardware Interface Test

A. Connect hardware simulator test box

B. Power "ON"

C. Terminal Connected

D. Turn "ON" all digital outputs through terminal. LEDs in Sunkeeper and simulator should light. Print drivers through terminal. Terminal should display PD 1-32. Turn digital outputs "OFF", LEDs should be unlit. Print drivers, terminal should display "PD".

E. Switch all digital inputs at simulator to "ON". LEDs in Sunkeeper should light. Print inputs through terminal. Terminal should display "PI 1-32". Switch all. "OFF". LEDs unlit, print inputs, terminal displays P.I. 
F. Turn all analog value pots on simulator all the way to the left. Print analogs through terminal. Terminal should display the number "64" for analogs $1-24$ and "224". for analogs 25 - 32. Turn all pots all the way to the right. Print analogs, terminal should display the number " 224 ". for analogs 1-24 and "64" for analogs $25-32$.

G. If any of above tests failed, troubleshoot and repair as required until all tests pass.

v) Environmental Tests
A. Power "ON"
B. Terminal connected
C. Enter program to sequence digital output "ON" and "OFF"
D. Remove terminal
E. Power "OFF"
F. Install Sunkeeper In test chamber and apply power "ON"
G. Set thermostat and humidity control to maintain specified limits.
H. Set time-clock to randomly turn power to Sunkeeper "ON"' and "OrF"
1. Leave Sunkeeper in test chamber for 48 hours. Record date, time, off test start and finish. Record temperature and humidity.
J. Remove Sunkeeper from test chamber
K. Test shall have been passed if program entered in " $C$ " above has been retained as verified by observation of output LEDs when power "ON" is applied to Sunkeeper outside the test chamber.




\section{B) Collector Circulation system}

Design: 15 G.P.M. @ $20 \mathrm{ft}$. max. external T.D.H.

Min. 4 Zones - 4.25 G.P.M. ea.

Max. 8 Zones - 1.875 G.P.M. ea.

Max, Operating Temp. $240^{\circ} \mathrm{F}$

Max. Operating Pressure 30 PSIG

Hydrostatic Test:

(Refer to Hydronic Test Set-Up Diagram)

1. Open Valves $V-1,2,3,7,10 \& 12$. Close Valve $V-14$.

2. Fill system with water and vent through air vent $v-16$. Close city water fill.

3. Close Valves $\mathrm{V}-12$ to array and open by-pass Valve $\mathrm{V}-12$.

Close Valves $V-12$ on electric water heater 13.

4. Start compressor and set pressure regulator to 45 P.S.I.G.

5. When compressor storage tank is charged, open Valve $V-14$ to pressurize system. Observe pressure gauges $6 \& 8$. Adjust compressor regulator as required to obtain 45 P.S.I.G. static pressure.

6. Close Valve $V-7$ and Valves $V-1$, zones $1-8$. Observe piping for leaks. If no leaks, allow system to remain as is for one hour and record following data:

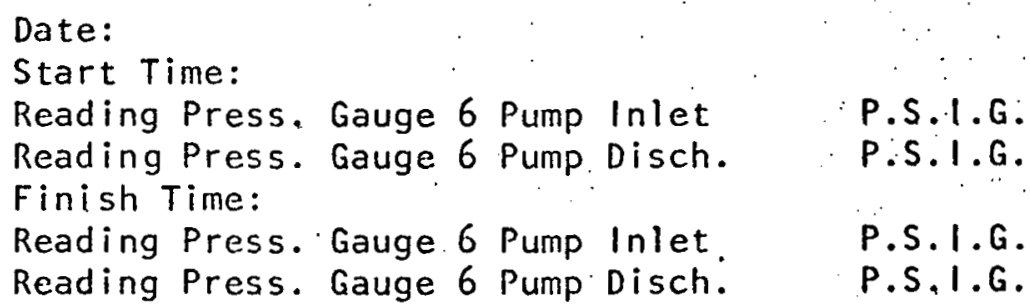

7. Open Valves $V-7 \& V-1$, Zone 1-8. Close gauge cocks on pressure gauges 6 . Adjust compressor regulator to obtain 125 P.S.I.G. static pressure. Observe piping for leaks. Record following data:

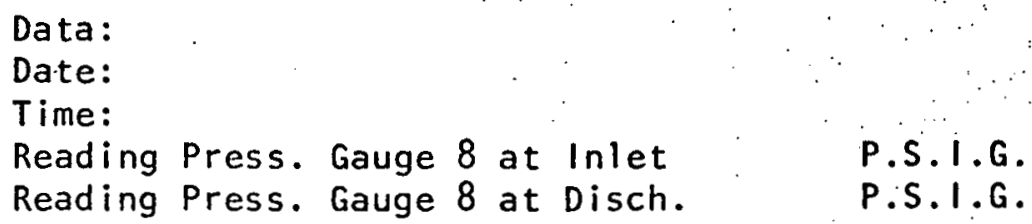

8. Close Valve $V-14$, open Vent $V-16$ to relieve static pressure to 30 P.S.I.G. and close. Open gauge cocks on pressure gauges 6 .

9. If leaks are found, repair and re-test until no leakage occurs.

Mydrodynamic Test:

(Refer to Hydronic Test Set-Up Diagram)

1. Open Valves $V-1,2,3,7,10 \varepsilon 12$. Close Valve $v-14$. 
2. Start compressor and adjust regulator for 30 P.S.I.G. When compressor tank charged, open $V-14$ and adjust regulator. to. obtain 30 P.S.I.G. static.pressure on system. Record following:

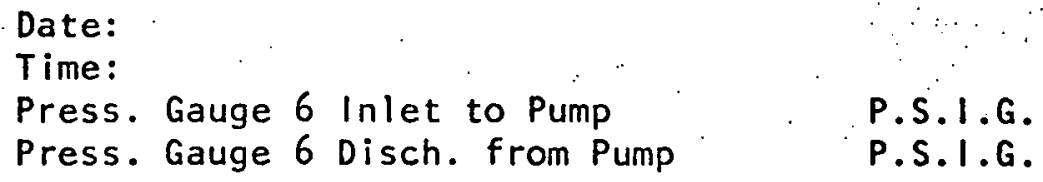

3. Preset zone balancing Valves $V-2$ for desired flow rate. Close. by-pass Valve $V-12$ to solar array: Close Valve $V-14$.

4. Operate pump 5 and observe pressure gauge readings at gauges 6 on inlet and discharge of pump. From pump curve determine flow rate for pressure drop across pump.

5. Adjuș balancing valvè lu to obtain design external pressure drop by observing readings of pressure gauge 8 : at inlet and discharge from I.P.E.C.H. sub-assembly. Determine flow rate as described in "4" above. Take preliminary flow readings at zone balancing valves $\mathrm{V}-2$. Check these against flow rate determined for Pump 5 , and adjust as required. Continue to make adjustments to Valves $V-2$ and $V-12$ until design flow rates across Pump 5 and in each of 8 zones are established with the specified external pressure drop.

6. When design flow rates and pressure drops have heen established, allow system to run continuously through the solar array. Add supplemental heat with electric water heater 13 until water. temperature reaches $240^{\circ} \mathrm{F}$. Check flow rates and pressure drops and adjust as required.

7. Record the following data:

A) Inlet pressure to pump

B) Outlet pressure from pump

C) Inlet pressure to I.P.E.C.H.

D) Inlet temperature to I.P.E.C.H.

E) Outlet pressure from I.P.E.C.H.

F) Outlet temperature from I.P.E.C.H.

G) Flow rate at balancing valves $v-2$. for each of eight zones

8. Close Valves $V-3$ of zones $1,2,3 \& 4$ in sequence. After each zone Valve $V-3$ has been closed, record data listed in " 7 " above. Open Valves $V-3$ of Zones $1,2,3, \varepsilon 4$. Close valves $V-3$ of zones $5,6,7, \& 8$ in sequence. After each zone valve $V-3$. has been closed, record data listed in "7" above.

9. Review data recorded in item "7" above. If recorded data is within specified limits, tested sub-assembly shall be accepted. 
If not tested sub-assembly shall be rejected. Determine cause of failure to comply and correct. Re-test sub-assembly until performance complies with specifications.

10. The purpose of procedure described in 1 tem "8" above shall be to insure that flow in individual zones shall not increase substantially when zone valves $V-3$ are closed. The object shall be to maintain constant zone flow rate regardless of the number of zones that are open.

\section{Zone Water System}

Design: 40 GPM @ $30 \mathrm{ft}$. Max. External T.D.H.

Min. 4 Zones 10 G.P.M. ea.

Max. 8 Zones 5 G.P.M. ea.

Max. operating Temp. $240^{\circ} \mathrm{F}$

Max. operating Press. 30 P.S.1.

Hydrostatic Test:

(Refer to Hydronic Test Set-Up Diagram)

1. Repeat Items I through 9 for hydrostatic test in Item "B" above.

Hydrodynamic Test:

(Refer to Hydronic Test Set-Up Diagram)

1. Repeat Items 1 through 10 for hydrodynamic test in Item "B" above. 
1. Sunkeeper Controller

$\begin{array}{llll}\text { Model No: } & \text { Volts } & \text { AC; } & \text { Power } \\ \text { Serial No. } & \text { Phase } & ; & \text { Cycles }\end{array}$

2. Solar Collector System Pump

Manufacturer

Serial No.

II. $\Gamma$.

Amperes

Volts $A C^{;}$;

Mndel No.

Phase ; Cycles.

$\mathrm{Hz}$.

3. Heating System Pump

Manufacturer

Serial No.

H.P.

; Volts

$A C$;

Model No.

Amperes

Phase

Cycles

$\mathrm{Hz}$ :

4. Zone Control Valves

Manufacturer

Volts AC; Phase

Solar System: Model No.

Heating System; Model No.

Cycles

Size

Size

5. Zone Balancing Valves

Manufacturer

Solar System: Model No.

Heating Systen: Model No.

; $\quad: \quad$ Size

6. Constant Flow Controls

Manufacturer

Solar System: Model No.

Heating System: Model No.

G.P.M. ;

Size

Control Range

Hz.; Amps

Size

Control. Range

P.S.I:D:

P.S.I.D.

7. I.P.E.C.H. Sub-Assembly

Manufacturer: SUNKEEPER CONTROL CORPORATION Model No.

Serial No. : 
A. SOLAR COLLECTOR SYSTEM TEST

Hydrostatic Test 45 P.S.I.G. Date:

Start Time: ; Rdg. Gauge 6 Inlet

Finish Time: ; Rdg. Gauge 6 Inlet

PSIG; Disch.

PSIG

PSIG; Disch.

PSIG

Hydrostatic Test 125 PSIG

Date: ; Time

Rdg. Gauge 8 Inlet PSIG; Outlet PSIG,

Hydrodynamic Test:

Date: ; Time:

Rdg. Gauge 6 Inlet PSIG;

Disch. PSIG;

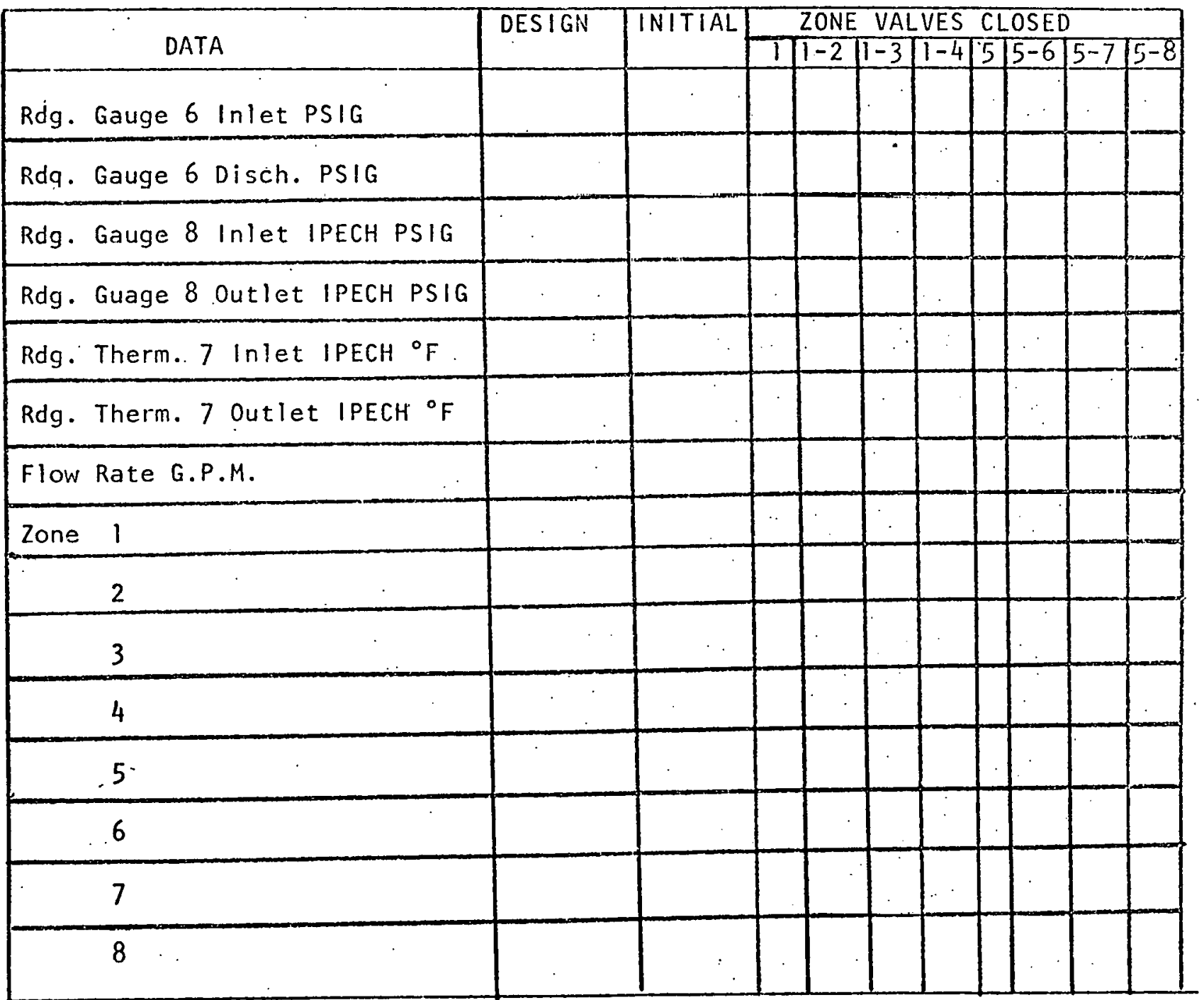

Accepted

Date:
Rejected

By: 


\section{B. ZONE WATER SYSTEM TEST}

Hydrostatic Test 45 P.S.1.G. Date:

Start. Time: ; Rdg. Gauge 6 Inlet

Finish Time: . ; Rdg. Gauge 6 Inlet

PSIG; Disch.

PSIG

PSIG; Disch.

PSIG

Hydrostatic. Test 125 PSIG

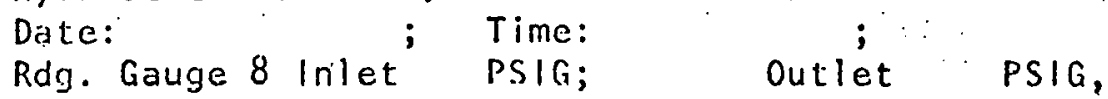

$\therefore \quad$ Hydrodynamic Test:

Datc: ; Time:

Rdg. Gauge 6 Inlet PSIG;

Disch. PSIG;

\begin{tabular}{|c|c|c|c|c|c|c|c|c|c|}
\hline \multirow{2}{*}{ DATA } & \multirow[t]{2}{*}{ DESIGH } & \multirow{2}{*}{ INITIAL } & \multicolumn{7}{|c|}{ ZONE VALVES CLOSED } \\
\hline & & & $11-21$ & $1-3$ & $1-4$ & $5 T !$ & $5-61$ & $5-7$ & $5-8$ \\
\hline Rdg. Gauge G Inlct PSIG & & & & & & & & & \\
\hline Rdg. Gauge 6 Disch. PSIG & & & & & & & & & \\
\hline Rdg. Gauge 8 Inlet IPECH PSIG & & & & & & & & & \\
\hline Rdg. Guage 8 outlet IPECH PSIG & & & & & & & & & \\
\hline Rdg. Therm. 7 Inlet IPECH ${ }^{\circ} \mathrm{F}$. & & & & & & & & & \\
\hline Rdg. Therm. 7 outlet IPECH ${ }^{\circ} \mathrm{F}$ & & & & & & & & & \\
\hline Flow Rate G.P.M. & & & & & & & & & \\
\hline Zone 1 & & & & & & & & & \\
\hline 2 & & & & & & & & & \\
\hline$\therefore 3$ & & & & $:$ & & & & & \\
\hline 4 & & & & & & & & & \\
\hline$\cdot \quad \cdot$ & & & & & & & $\therefore$ & & \\
\hline 6 & & & & & & & & & \\
\hline 7 & & & & & & & & & \\
\hline 8 & & & & & & & & & \\
\hline
\end{tabular}

Accepted

Date:

\section{Rejected}

By: 
TEST SET-UP 
4.S. GOVERNMENT PRINTING OFFICE 1979-640-081/499 REGION NO. 4 